\title{
Revisiting Reuter: Symbolic and material economies in Bali aga society
}

\author{
Alexander R. Cuthbert ${ }^{1}$ and G.A.M. Suartika ${ }^{2}$ \\ ${ }^{1}$ The University of New South Wales \\ ${ }^{2}$ Udayana University \\ Email: A.cuthbert@unsw.edu.au
}

\begin{abstract}
'History, Stephen said, is a nightmare from which I am trying to awake'.

(James Joyce)

'The distancing rhetoric, denial of history, negative description, negative targeting, and other marginalising strategies of a modern Balinese administrative elite are directed toward Bali Aga culture as a legitimisation for its systematic and deliberate eradication'
\end{abstract}

(Thomas Reuter)

\begin{abstract}
The objective of this paper is to analyse Thomas Reuter's seminal text The Custodians of the Sacred Mountains and to discuss some of the theoretical and other issues that flow from the reading. Indirectly it is also intended to assist many local scholars who find the text somewhat impenetrable, let alone making connections to its extensive implications. The book is the second study to emerge that covers the regional basis for the Bali Aga, the first being that of Wälty (1997). The text is one of a kind - erudite, complex and intellectually challenging. The paper begins with historical interventions since the status economy of Bali Aga is wholly dependent on a mythical past. Next, the use of theory, focussing on anthropology and Bali studies is discussed to place Reuter's work in context. Then his basic concepts are analysed, those of precedence, status, and representation. Subsequently, we focus on place and space since geography is a defining feature of Bali Aga. Finally the mental (symbolic) and material (political economy) dimensions are contrasted with the observation that omission of any consideration of the latter weakens an otherwise seminal work.
\end{abstract}

Key words: symbolic economy, political economy, culture, 
status, representation.

\begin{abstract}
Abstrak
Artikel ini mengkaji aspek teoritis serta isu lain yang muncul setelah membaca karya penting dari Reuter, The Custodians of the Sacred Mountain. Keberadaan artikel ini juga dimaksudkan untuk membantu para peneliti lokal yang mempunyai kendala dalam membangun koneksi serta implikasi luas yang dimiliki karya ini. Buku ini merupakan studi kedua yang membahas dasar-dasar regional komunitas Bali-Aga, setelah yang pertama dilaksanakan Walty (1997). Analisis di dalam karya Reuter memiliki kompleksitas yang secara intelektual menantang. Manyadari bahwa kondisi sosio-ekonomi masyarakat Bali Aga, secara keseluruhan, tergantung pada mitos masa lampau, maka kajian ini diawali dengan pemaparan historis. Pemanfaatan teori terkait antropologi dan studi tentang Bali dilakukan untuk mengkontekstualisasikan analisis terhadap pemikiran yang ditawarkan Reuter. Selanjutnya, dilakukan kajian terhadap konsep-konsep yang dibangun Reuter, termasuk yang berhubungan dengan penerus tampuk kepemimpinan, status dan wujud representasinya. Mengingat aspek geografis merupakan fitur penentu dari komunitas BaliAga, maka diskusi dalam artikel ini difokuskan pada tempat dan ruang, Di akhir, dimensi simbolis (mental) dan material (political economy) dikontradiksikan dengan pengamatan, di mana absennya pertimbangan terkait dimensi material telah melemahkan konsepsi yang dibangun Reuter dalam karyanya, yang seharusnya merupakan referensi ilimiah yang penting dan berpengaruh.
\end{abstract}

Kata kunci: ekonomi simbolik, ekonomi politik, budaya, status, representasi

\title{
Introduction.
}

7 he work in question -Thomas Reuter's book Custodians of the

Lacred Mountains (2002) is a prodigious work of scholarship. While not the first regional study, it is without doubt a ground breaking intervention into the highland peoples of Bali. It also makes a significant contribution to research on Austronesian peoples in general. It provides the first comprehensive regional study of Bali's original inhabitants, commonly referred to by outsiders 
as Bali Aga (mountain people) or otherwise Bali Mula or Bali Kuna (original or ancient Balinese), all terms imposed by lowland culture. Wong Bali simply means 'people of Bali' and arguably applies to all Balinese. Visions of the Bali Aga from this perspective are clearly very different to the identity they have of themselves, and this fact remains a central analytical exigency in the text. In Tenganan, probably the best known traditional village, the people do not describe themselves as Bali Aga, merely as Tenganan.

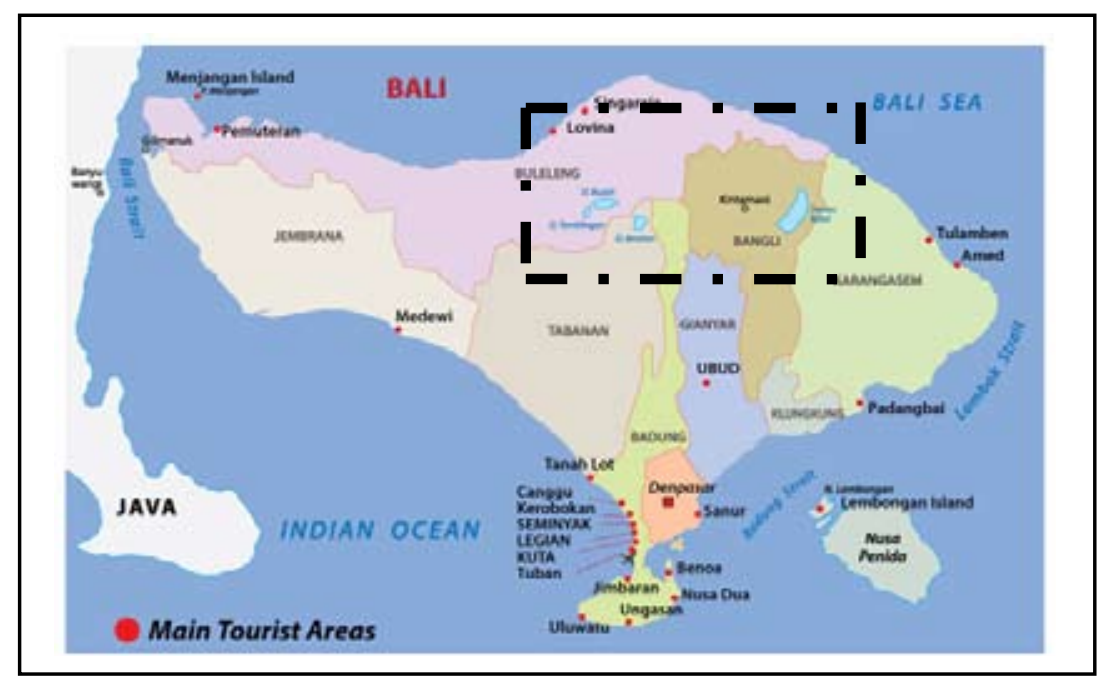

Figure 1. Map of Bali. Approximate delineation of Bali Aga territory.

Even after a century of study the existence of Bali Aga as a discrete and separate collectivity remains partial, due to the inevitable shifting landscape between geography, economy, social relations, intermarriage, and settlement typologies etc., which are not hermetically sealed from each other. Many factors impinge on the Bali Aga as a singularity. Nonetheless Reuter lists very clearly the characteristics he considers that all Bali Aga communities share in the second volume of his ethnography, The House of our Ancestors (2002). Overall the mountain people prefer the name Bali Aga despite its potential for abuse, so its accommodation is somewhat malleable (272).

So we may argue that the singularity Bali Aga exists, but as an imaginary construct, and that the term is contested among lowland Balinese people, anthropologists, and prior colonisers as to whom the 
real, original, or first Balinese happen to be. While mountain people might regard themselves as the true Balinese, genetically, some $12 \%$ of Balinese Y-chromosomes are of likely Indian origin, while $84 \%$ are of likely Austronesian origin, and 2\% of likely Melanesian origin (Karafet et al 2005). The study does not correlate the DNA samples to the Balinese caste system. In other words the coherence of Bali Aga culture as a discrete social form given the 'staggering complexity' of its socio-spatial organisation is open to question. Also arguable is any claim to be the 'original' Balinese, since the DNA of all Balinese is predominantly from a single source despite the encroachments of the Majapahit era. Overall Bali Aga culture contains such immense spheres of difference that few characteristics exist to identify uniform coherence, one to which all communities and social practices comply. Rather, there is a grouping or a graded association of different villages and temples inhabiting a specific geography (Banua). Each banua engages with an identifiable micro-territory that has its own identity and difference, yet it shares specific religious institutions and rituals with others. There are always exceptions. For example there is not much that the Tenganan share with other Bali Aga except religious associations. Paradoxically, and like several other Bali Aga villages, Tenganan is not in the mountains at all, and exists only four kilometres from the sea near Candidassa, being described by Covarrubias in 1937 as 'A unique, rabidly conservative and strictly tribal community (p20 fn.3).

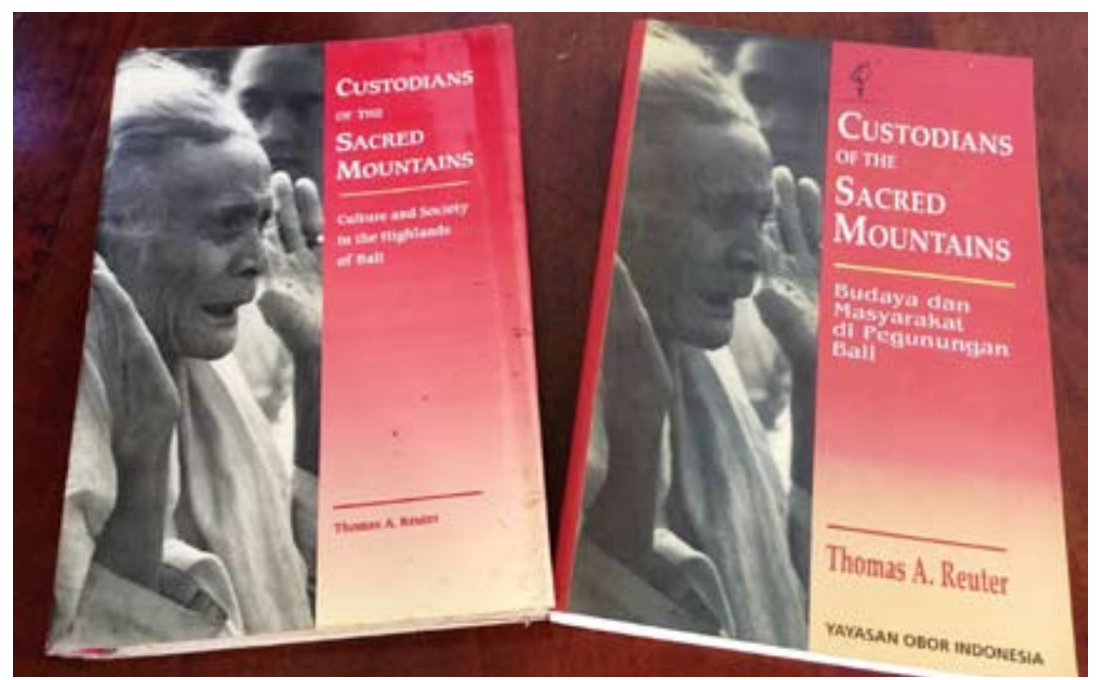

Figure 2. The book and its Indonesian translation. 
As an ethnographer and an anthropologist Thomas Reuter's theoretical and epistemological position is guided by a specific research paradigm. While the books title alludes to its prime function as a regional study of ritual domains in the highlands of Bali, it has at least two other trajectories. The second is to advance knowledge of the entire Malay-Polynesian-Austronesian indigenous people, stretching from Java through Tonga and Fiji to New Zealand to which Wong Bali belong. Bali Aga arguably share as much with Hawaiians as they do with Lowland Balinese who claim descent from Javanese conquerors. Notably the Javanese are also Austronesians, as are virtually all Indonesian peoples. The reason why the Lowland Balinese differ is cultural change, while the Bali Aga have been more conservative as many mountain peoples tend to be. In addition, their attitude is a reflection of their intimate link to pre-Majapahit Balinese kingdoms.

In the wake of many anthropologists, Reuter's third objective is to establish a dialogue with theory, to establish hypotheses and to arrive at a new understanding of human society as a whole. This is indeed a difficult journey, and despite its excellence, it remains debateable as to whether or not this has been accomplished. The second section of the book has come under some criticism as to the role of his ethnographic research to the larger question of the cultural production of knowledge. In calling for 'a fundamental and general critique of all representational systems seen against the backdrop of the subject matter of the book, this statement seems to me to be a bit oversized' (Schulte Nordholt 2003:134). This critique was paralleled by some serious questioning of the central role in his thesis of intersubjectivity. While arguing in agreement with Reuter that it may be 'fundamental to the cultural construction and contestation of knowledge', it rarely if ever is voluntary and free, 'undistorted by the influence ...... of glaring asymmetries in wealth and force' (Pedersen 2003:171). Adding to such complexity, his thesis that Bali Aga have a status economy is not new to social science. While new to Bali studies it is echoed in contemporary, post-modern social theory, which argues similarly that a status economy is now an encompassing feature of contemporary society. This dynamic is not pursued in his text, a subject that could have been singularly revealing - the idea that a coherent analysis of Bali Aga can contribute to social theory as a whole which is the goal of 
major theorists in the field. But in order to comprehend what he is saying, it is necessary to engage in some rather heavy theoretical problems and debates, otherwise no real understanding of his work is possible beyond the superficial.

\section{The Confusions of History}

The seminal question here is can history be theorised? If it cannot, then we need go no further. In turn this question reflects on research into Bali Aga since their entire existence as in many cultures, depends on an ingrained process of historical succession. Thus interpreting, or in their case reinterpreting history represents the intrinsic dynamic of their social structure. As with other early people, their history has been written and rewritten, often by decree, for example the Incas of Peru who had professional scribes to transact their history at any given moment. So what is new? This is not much different for contemporary cultures either e.g. the official Japanese version of the war in SE Asia, versus the accounts of the people whom they invaded. How history is theorised is therefore a paramount consideration in ethnographic research since even objective 'truths' can be interpreted to suit the interests of the narrator. How then are we to proceed, at least in terms of a critical reading of history? - Or as we shall see, that a critical writing of history is itself a paradox in the case of Bali Aga. The only written evidence of early Balinese history are the prasasti found in Bali Aga villages. Hence we have only a partially 'true' history from these royal inscriptions written in old Balinese with added Sanskrit elements.

Most regions of academic endeavour are theoretically informed, either from the natural or social sciences. In ethnographic research, a tenuous relationship exists between the method (ethnography) and the adoption of a theoretical interpretation of history. While these are not necessarily mutually inclusive events, the idea 'that history explains nothing since it too must be explained' is perceptive (Godelier 1985:70). The relationship between history and theory is problematic, and we even have Francis Fukuyama's speculation of the End of History (Fukuyama 2006). So should history merely recount diachronic events, a linear stream of meaningless dates and times or should these events be interpreted? If so by whom, according to which principles, and for what purposes? True or otherwise, the proposition that history has no theory, 
and that indeed it cannot have valid theory has been eloquently argued in Why is History Anti-theoretical? (Duara1998). While much ethnographic research (frequently a pastiche of methods in search of theories) - is largely factual and descriptive, Duara argues:

First, history has no theory because there are no satisfactory models for theorising over time, over flux and change, - the object of historical knowledge...It is in the nature of things to change in time, and that is why the narrative mode is so appealing. The borrowing of theory from elsewhere has also reinforced the alienation of history from theory, since this theory has not emerged from problems intrinsic to historical change (Duara 1998:106).

The writing of history is antitheoretical, first, because it is the principal means of naturalizing the nation-state as the container of, or the skin that contains the experiences of the past....Critics will point to obvious exceptions such as Marxism and the Annales School, among others. In response, I argue that these exceptions have not sufficiently exposed the fundamental connections between the nation-state and the linear mode of history (Duara, 1995a: chapter 1).

In contrast, Mary Fulbrook in her classic Historical Theory, distinguishes between historical paradigms and theoretical traditions. She states that in the twentieth century, 'history was about telling the truth' but with the onset of postmodernity 'history dissolved into relativistic discourse...the truth could not only never be known, but was itself merely an article of faith. Historical works were merely fictions written in realistic mode...the vast majority of practicing historians ignored the unintelligible theorists and simply got on with the job of reconstructing the past' (Fulbrook 2002:3). If we follow this logic we quickly arrive at the point that much prior historical theory is the theory of fictitious events. Fulbrook is also against the postmodernist trend towards endlessly depoliticised 'narratives' - 'vague notions of multiple, simultaneous competing perspectives among which one can only choose on the grounds of personal preferences' (Fulbrook 2002:30). To 'perspectives' we could add an infinite number of 'texts,' 'voices,' 'discourses' and 'others'. Reuter shares this idea, and his ambivalence if not his antipathy to postmodern anthropology is evident. Samir Amin arguably nails the idea when he says 'the critique of capitalism antedated the faddish critique of capitalism now offered us by postmodernist theoreticians. The point is to judge whether or not postmodernist theory offers any fresh insights. I consider postmodernism to be an 
intellectual non-starter' (Amin 1998:136).

Consequentially or otherwise, Duara considers that only two schools of thought (paradigms) have emerged that have value. The first is Marx' theory of history embedded in the idea of historical materialism, that society is determined at any given moment by the material conditions of existence - by the things people need to do to provide the basicnecessities of life. This has five main developmental stages - primitive communism, slave society, feudalism, capitalism, socialism, and communism. These correspond in greater detail to what he termed modes of production - the forms underpinning specific stages of historical development, where movement from one to another was determined by the necessary storage of surplus value that allowed new social relations to evolve. This did not discount the idea that the residue of several modes could co-exist with the new, as in postmodern capitalism and proto feudal/tribal society in Bali (Desa Adat). Yet Marx poorly theorised 'Asiatic societies', lumping them in with South America, and it was Wittfogel who posed the more specific concept of oriental despotism and hydraulic society. Prototypically these constituted forms of despotic rule, in turn facilitating highly organised systems of irrigation and the social constructs that accompanied them.

The Lowland Balinese Subaks comprised one such typology. Despite this, there are significant arguments against both Wittfogel and Marx on the basis that that Balinese subak has a certain autonomy of its own, where descriptors such as feudal, quasi feudal, proto feudal, hydraulic or tribal appear inadequate. This creates an interesting analytical problem if in fact no prior similar examples exist (how then can comparative studies be done?). Interestingly, if we define a tribe as a hierarchically politicised group, 'it may also be an internal response to the necessity of defence against imperialist efforts to dominate a given area' (Bottomore 1983: 488). This raises the question as to the effects of Dutch imperialism on Bali Aga, and whether or not it actually contributed to their identity as mountain people. We do not wish to dwell on this here but refer readers to the classic references on the subject (Wittfogel 1981, Cohen 1978), and of Marx' own German Ideology (1981). Simplified, we can say that Marx developed his sophisticated theory of historical materialism based upon his own extensive research and undeniable genius. Like most of Marx' work, his modes of production have been attacked from all 
sides, while remaining invaluable to the theory of history. What is critical is not whether these concepts are true, but how much truth they still contain.

The second theoretical mode or form of interpretation is the Annales School. Up until the commencement of the First World War, political history dominated in the determination of nation states, predominantly involving accounts of imperialist expansionism and the wars it necessitated. As a counterpoint to this situation, and arguably inspired by Emile Durkheim, Marc Bloch and Lucian Lefebvre founded the Annales D'Histoire Economique et Social in 1928, usually referred to as the Annales School. It remained somewhat marginal in social theory until it emerged as a force in its own right after World War Two, with Fernand Braudel and Roland Barthes playing major roles 'This also included a rejection of quantitative methods for a more qualitative orientation with human subjectivity, psychology, consciousness and culture, as well as Marxian notions of ideology' (Cuthbert 2011:34). In other words abstract concepts of truth and objectivity were cast to one side in order to explore how it felt to be in history. In order to express this experience, subjectivity came to the fore, and how history was written provided credible opposition to the rampant claims to objectivity pursued in the name of furthering nationalism and the nation state. In so doing the proscribed linearity of historical progress was abandoned, one promoted in the West by Christianity which perceived of history as a linear, finite process which began with a week of frenetic activity and will conclude with the second coming of Christ (the rapture), perhaps sometime in the future.

All of this has a bearing on how Reuter approaches his study - dominated by the hypothesis of a symbolic or status economy providing a satisfactory theoretical explanation of Bali Aga culture as a whole, one situated in a reading of their historical evolution into a discrete social identity. We would argue that the term economy is misused here. If indeed status is the foundation for social life, then in Marxian terms it becomes the means of production, yet nothing is produced. After centuries of such oral histories communicated via the mythologies of the Bali Aga, it may be argued that what remains is located in the realm of fantasy due to the subjectivity of stories being transposed from individual to individual and generation to generation, despite the fact that limited written 
sources may confirm the partial content of oral history. Reuter himself recognises this when he says 'Banua are produced and reproduced, changed, maintained by people in the present as they engage in specific social practices and discourses designed to "read" and 'write" history' (33), or alternatively 'that the past is created in the image of contemporary concerns'(98). Similarly, if a village has at some time been abandoned the moment of original unity is thus represented by a socially vacant origin site' (41). In addition, the idea of a constructed collective identity is similarly fragile in the case of Pura Batur, a regional centre of Bali Aga which does not consider itself a Banua, choosing instead to refer to itself as friends of the temple. While this may be a special case, there is some credibility in the idea that every Banua is to a degree a special case, making a generic study that much more difficult to expedite (e.g. Tenganan, Batur, Penglipuran, Sidatapa etc.).

After Michel de Certeau, the idea that history becomes the myth of language seems relevant in the context of the Bali Aga. So it is necessary to examine some of the exigencies of their history, since the debate remains as to whether the Bali Aga arrived on the island any earlier than other Balinese, calling into question whether or not their singularity depends solely on mythologies, or is consequent upon other issues. Given these confusions in regard to history and the dependency by Bali Aga on mythical historical origins, we will now provide a brief consideration of theory in the natural and social sciences. This will then allow us to situate Thomas Reuter's chosen paradigm, that of Anthropology, and its relation to Bali studies.

\section{Approaching Theory}

Reuter's stress on the major implications of subjectivity in ethnology are reflected in the concept of a reflexive sociology, an idea originating in the work of Pierre Bourdieu (1977, 1986). This proposition embodies the idea that the essential subjectivity of all investigators is an impediment to 'the truth', which as we have noted above is a somewhat negotiable concept. As such ethnologists must reflect on their own perceptions, learning, social status, religion etc. All of these bring their own bias, and stand as a significant impediment to objectivity. Each will affect the nature of outcomes in any interactive dialogue with other individuals or social groups. If you believe in god, then it is difficult to omit this 
belief from an investigation of origin peoples who do not believe in her. Juergen Habermas in his seminal work The Theory of Communicative action addresses the idea of distorted communication as the fundamental problem of society as a whole (1970,1979). Habermas phrased the problem by rejecting economic production as primal, replacing it with language -'For Habermas therefore, language is the mother lode of social organisation, defining both the mental and material aspects of our existence' (Cuthbert 2011:267). But due to its inherent capacity for distortion, language therefore becomes a highly politicised arena, variously serving to manipulate, compromise, control, or otherwise deprive human society of relevant information (power).

Reuter proceeds by resorting to several defining statements and key concepts. He begins with the position that the purpose of the book 'is to explore a complex web of asymmetric status relationships' in regard to Bali Aga (4). Significantly:

The basic communicative processes in social games of mutual representation are more easily revealed by examining cases where the stakes are predominantly symbolic [resources] rather than material resources, and by employing a status economy approach rather than a political economy model of analysis.... I hypothesise that the symbolic economies of the Bali Aga and other status oriented societies rest on a fundamental paradox. An ongoing competition for (and asymmetrical distribution of) symbolic resources is made possible and is simultaneously constrained by an intrinsic need to cooperate' (4).

The problem as noted above in regard to modelling is that if any society is to be understood, it must be understood in its full complexity, and such understanding cannot be reached by simply deleting political economy from the model (Sayer 1976). A central struggle in the text is therefore between subjectivity, or more accurately intersubjectivity (representation) and a debateable objectivity (science). At another level, there is also a conflict of interpretation, between Marxism (and its offspring) and Postmodernism. Marxism is of course Political Economy in a more acceptable 'representation'. While Reuter does not say that political economy is unimportant, he simply says that it is a level playing field between the two conceptual frameworks. Reuter posits the case for symbolic representation (after Bourdieu) being a more 
encompassing form of explanation of what he calls the status or symbolic economies of the highland Balinese without any critique of the alternatives. He defines his terminology by saying that 'status systems are the culture - specific products of a history of collective representational labour' (10).

So Reuter's study is not only extensive in scale but also in reference to major scholars in the social sciences such as Pierre Bourdieu, Eugene Habermas, Arjun Appadurai, Edward Said, Paul Ricoeur, Anthony Giddens, Jos Platenkamp, Louis Dumont and others. He also mentions Claude Levi-Strauss, a structuralist anthropologist whose life's work was directed to unearthing the universal foundation for the mythologies of indigenous people (1968, 1978). This idea is central to Reuter's entire conceptual system where mythologies provide the legitimation for status systems - but the principle is deployed differently in his study. It would be enlightening to know how Reuter's analysis of the mythology of Bali Aga relates to Levi Strauss' mythologies and structuralist methods. While both scholars are recognised as passé in contemporary anthropology, Levi Strauss and Marx had different conceptual infrastructures, the mythic and the material. Neither is discussed despite the vast inheritance in the development of their ideas. This leaves Reuter's concentration on status in something of a void, since these relations are not illuminated in reference to their historical trajectory and contemporary relevance in anthropology. It is left to Godelier to explore the idea:

Until very recently, there were numerous societies which knew neither castes nor hierarchized classes. Now in this type of society the relations of production do not exist in a separate and distinct state, as they do in capitalist or "socialist" society, where the production process is seen to operate in an institution.....the distinction between infrastructure and superstructures is neither a distinction between levels or instances, nor a distinction between institutions.....in its underlying principle it is a difference between functions......A society has neither a top nor a bottom, and it is not a system of superimposed levels. It is a system of relations between human beings, relations that are hierarchized according to the nature of their functions; these functions determining the respective impact of each of their activities up-on the society's reproduction (Godelier 2011, 52 and 128).

So without referring to status, Godelier suggests more generalised principles that Bali Aga seem to fit, stressing the nature of functions 
rather than institutions as deterministic of the form their society takes. By functions Godelier means those processes 'determining access to and control over the means of production (2011:28). Once again the comparison that springs to mind is that of Bourdieu's work on taste, status and the symbolic economy of postmodernity. The fundamental difference between these two poles - Bali Aga and Postmodern culture, is that in the former, Reuter argues the status economy is primal, and its legitimation is backward looking to origins. In the latter, the material economy comes first, along with the progressive accumulation of symbolic aka cultural capital and the world of commodity fetishism upon which a status economy is based. The idea also relates strongly to the concept of taste which refines class distinctions. These ideas will be discussed in greater depth below.

\section{Anthropological Perspectives}

Each of the main theoretical approaches to anthropology has its inherent methodologies - political economy, structuralism, functionalism, cultural evolution, diffusionism, hermeneutics, historicism, feminism etc. This list may vary depending on the discipline and are in a continual state of flux. In this context it is difficult to place Reuter in a box. Theoretical boxes pretty much disappeared from anthropology since the 1990s as indicated in Fulbrook (above). Idiosyncrasies apart, it is important to recognise that Reuter is a social anthropologist and his method is that of ethnography. From this point on, things become less simple and it is important to recognise three things. First, that the Oxford dictionary defines anthropology as the comparative study of human societies and cultures and their development (Hobart 2000). Second, that ethnography is the scientific description of peoples and cultures with their customs habits and mutual difference (Agger 1992). Third, in the case of Bali Aga, that history plays a significant part in the overall process both ancient and recent, no matter how much these histories have been distorted, translated or their potential evolution misinterpreted.

Collectively these three dimensions of the investigative process are intertwined in Reuter's approach to Bali Aga. Several questions emerge from these observations each of which is significant. For example does anthropology conflate to ethnography as might 
appear - are they the same thing? (see Ingold, T. 2013, 2015). Since anthropology is a comparative discipline, can societies and cultures justifiably be studied in isolation, as we discover in many studies of isolated Balinese villages? If anthropology deals with development, how is development to be defined, and whose definition should we adopt? Clearly anthropology cannot be reduced to one definition of development (such as e.g. the economic, political and symbolic structures that facilitate capital formation). On the other hand we cannot proceed from a variety of different conceptual systems, and risk falling into a depoliticised postmodernity. So we are sympathetic to a materialist position despite its apparent flaws. The same principle applies in regard to a reading of history, but for the moment let us examine some implications of the above for Reuter's approach.

Notably anthropology is subsumed to social science in general where the big question is whether or not social 'science' is the correct terminology. In Giddens Sociology he asks this exact question - is sociology scientific? Since science constitutes the use of 'systematic methods of empirical investigation, the analysis of data and theoretical thinking,' he states categorically that 'Sociology is a scientific endeavour'......my conjecture is that cross-cultural representation is a necessary and legitimate enterprise, after all and under certain conditions' (2009:41). In other words he has discounted the idea that subjectivity is by definition a process of distortion and that individual observations remain highly subjective. Whereas to be scientific, observations should be impartial, objective and demonstrable in repeated observations or experiments. This conjuncture permeates social science, and ethnographic research in particular, one which by its very nature would imply an 'unscientific' process, although this idea of science has itself not gone unchallenged (Feyerabend 1975). While it may be claimed that the realm of subjectivity is an objective reality that can be observed, this argument becomes challenged in the context of counter- representation, where what counts are individual's observations of themselves. Natural science and social science study entirely different phenomena, but it is clear to social science that the study of human beings is rather different from the study of physics e.g. the Higgs - Boson particle. In other words 'Any conception of society - whether lay or scientific - which treats 
people as passive objects of history and mere carriers of knowledge, rather than agents or producers is doomed to misrepresent both its object and itself' (Sayer 1998:23).

So there are no laws in anthropology that correspond for example to the laws of physics, although Levi - Strauss whom we will address later, has approached this idea in some respects e.g. in the structuralist approach to mythology $(1969,1978)$. Indeed it has been argued by Radcliffe - Brown, another structuralist, that such laws are both possible and necessary, an idea Levi-Strauss resisted. There is also the vexed question as to whether there can be any sharing of theory across disciplines. This clearly affects the use of specific methodologies particularly ethno-methodology, in uncovering new facts and advancing new theoretical perspectives. While we may argue that social science is fundamentally subjective, whereas natural science claims objectivity, largely due to the subject matter it embraces, this argument is somewhat simplistic, and it has been debated from both ends of the theoretical spectrum. On the basis that an ostensibly 'scientific sociology' would be concerned with social control, whereas a radical sociology would focus on liberation from existing tyranny. Noble comments 'thus one sociology is no more scientifically neutral than the other' (2000:13). Both are equally subjective, and how one deals with this inherent and unavoidable subjectivity is not only at the heart of anthropological research in general, but also to Reuter's research in particular. He attempts to avoid such bias through the process of counter-representation, recording how people see themselves rather than deducing facts about them from so-called objective 'data'. This concept appears to parallel that of Anthony Giddens who proposed structuration theory in order to recognise the duality of structure 'whereby social structures are both constituted by human agency and yet at the same time are the very medium of this constitution' (Blaikie 1993:73). Nonetheless ethnography cuts across many theoretical categories as a somewhat universal method, since the observation and recording of social facts constitute a central process in social science. It has also constituted the adopted method of many anthropologists studying Bali, with the possible exception of Margaret Mead who was the first to use photography as an analytical tool. 


\section{Time, Space and Production}

A great variety of scholars, mostly ethnologists focussing on villages, have contributed to Bali studies (Cribb, R. 1990, Geertz, C. 1973, 1980, Ramseyer, U. 2009, 2002, Vickers 1989). A few others (largely the non-ethnologists) - have taken different approaches, focussing on political and economic factors, e.g. Robinson 1995, Mehr, 2000, Lewis and Lewis 2009. Notably in-depth studies of Bali Aga are singularly absent. In addition, these prior founding ethnological studies were somewhat introverted:

Important as they were as anthropological studies, to a political historian, these early post-war years are remarkable for their lack of attention to time, place, or historical and political context beyond the village level.....(Robinson 1995:8, 9)

This arguably remains the case to date, and while studies of Bali Aga society have been extensive, they have been pursued in fragments. Prototypically, while Ramseyer's text The Theatre of the Universe is an exceptional exposé of Tenganan, it remains the study of a single village. Consequently,

'With the case study of Bali at the focus of attention for so long, one could be excused for assuming that further ethnographic research is unlikely to produce major surprises or new discoveries' (1).

As a counter to this idea, Custodians of the Sacred Mountains is a serious piece of ethnographic research that goes far to obviate Robinson's critique (above). As noted, what distinguishes it from the other studies is its focus on regionalism. While certain village studies are classics such as Ramseyer's The Theatre of the Universe - Ritual and Art in Tenganan, they do not contribute significantly to identifying and consolidating the society of Bali Aga. Nor indeed do they help to determine their actual existence beyond speculation and guesswork. Such cloistered ethnographic research has time as its focus. What happens in a village, when it happens, and how things change are examined at a micro level. We could be heretical and suggest that in studying a specific village, anthropologists cannot actually know they are studying Bali Aga, except perhaps by extrapolating from other research on a different village. The critical rule here is that if ethnology is to be scientific, the general cannot be assumed from the specific. Reuter's research was among the first 
to correct this situation in Bali. Whether or not the conclusions as to Bali Aga have any implications wider than their own geography remains to be demonstrated.

Rather than time, in Reuter's research it is geography that is key. Bali Aga live in and through space across a distinct region from which much of their externally perceived identity flows, arguably for the wrong reasons (alienation, poverty, backwardness, etc.). Since regionalism is an essential component of their identity as a 'people', Reuter suggests that the linkage is via theories of status, and as method, a concentration on the concept of representation or otherwise counter - representation in situations where an ethnographer encounters major local power differentials and associated marginalisation discourses. He refutes the 'gloomy perspective' of post-colonial and post-modern approaches, and challenges much pre-existing social science that resource competition is the defining force in cross cultural encounters. In its place is substituted the idea that representational labour is the origin of status. What Reuter implies is that Bali Aga culture is not structured through its need to produce the basic necessities of life, as it might be from a Marxian perspective, but through a complex ritual hierarchy based on mythical ancestral histories. Despite the focus on the symbolic economy, it does not seem that these two positions need be mutually exclusive.

But if one is sympathetic to social analysis derived from political economy as we are, Reuter's research scaffolding omits the idea that all human societies must first produce the material basis for life before any symbolic complexity can occur. So a surplus material product has to be produced - man acting on nature before any unproductive labour can be afforded. Neither does this imply that a class structure is a necessary outcome, particularly in Bali Aga culture. But crudely stated, survival must come before ceremony. The more complex the rituals, the more time is removed from productive labour. Or alternatively, the wealthier a society is, the more time it can spend on reproducing culture through artistic, ritual and ceremonial functions. This would imply that Bali Aga with its extensive (and expensive) festivals, rituals and performances is a wealthy society, since Reuter indicates that local communities have to bear the frequently 'enormous economic burden of the villages ritual performance obligations'(246). So the 
question is where does this wealth come from? In Reuter's book, the material basis of life for the Bali Aga is almost entirely omitted from the equation. Paradoxically, it is also clear that Reuter is conscious of this omission when he states 'this is not to deny that Bali Aga society has an economic and political economy, as it certainly does' (245), but significant elaboration of this fact would have helped to qualify the overarching stress on the concept of status. Therefore a clarification of this situation is required by a more complex approach to Reuter's key reference points - those of precedence, status and representation.

Table 1: Generalised differences between Bali Aga Culture and Lowland Balinese culture.

\begin{tabular}{|l|l|l|}
\hline \multicolumn{1}{|c|}{ BALI AGA CULTURE } & \multicolumn{1}{|c|}{ LOWLAND BALINESE CULTURE } \\
\hline 1 & $\begin{array}{l}\text { Do not recognise Majapahit } \\
\text { origins. Most origin myths } \\
\text { claim an origin in Bali. }\end{array}$ & $\begin{array}{l}\text { The source of Brahmana civilisation } \\
\text { is recognised as Indian (Hinduism) } \\
\text { sourced from Java. }\end{array}$ \\
\hline 2 & $\begin{array}{l}\text { The dead are not cremated. } \\
\text { Instead, burial, or the use of } \\
\text { air funerals (e.g. Trunyan) are } \\
\text { deployed. }\end{array}$ & $\begin{array}{l}\text { Dead are cremated in Ngaben ceremonies } \\
\text { according to complex mores and rituals }\end{array}$ \\
\hline 3 & $\begin{array}{l}\text { Social class and caste do not } \\
\text { exist. Differences in material } \\
\text { wealth are insignificant. }\end{array}$ & $\begin{array}{l}\text { Social hierarchy established on the basis } \\
\text { of caste, class, monarchic proximity and } \\
\text { material wealth. }\end{array}$ \\
\hline 4 & $\begin{array}{l}\text { Lowland Balinese priests have } \\
\text { no official roles in Bali Aga } \\
\text { hierarchy. }\end{array}$ & $\begin{array}{l}\text { Bali Aga ritual hierarchy is not } \\
\text { recognised. Lowland priestly functions } \\
\text { are largely monopolised by the } \\
\text { Brahmana 'caste' }\end{array}$ \\
\hline 5 & $\begin{array}{l}\text { Use Sanskrit mantras but } \\
\text { less frequently than Lowland } \\
\text { practices. }\end{array}$ & $\begin{array}{l}\text { Sanskrit used ceremonially (mantras) } \\
\text { and in written documents. }\end{array}$ \\
\hline 6 & $\begin{array}{l}\text { Village leaders have greater } \\
\text { symbolic capital than others } \\
\text { via historical association, but } \\
\text { do not form a status class } \\
\text { because leadership is rotated } \\
\text { according to precedence }\end{array}$ & $\begin{array}{l}\text { Village leaders are elected. Without state } \\
\text { sanction "royalty" remain respected by } \\
\text { Balinese people. }\end{array}$ \\
\hline
\end{tabular}




\begin{tabular}{|c|c|c|}
\hline 7 & $\begin{array}{l}\text { In general, the climate denies } \\
\text { any possible rice cultivation } \\
\text { in most Banua, and is ritually } \\
\text { prohibited in Penulisan and } \\
\text { Batur. }\end{array}$ & $\begin{array}{l}\text { Society founded on rice growing and } \\
\text { the system of subaks or what has been } \\
\text { termed hydraulic engineering (Wittfogel } \\
\text { 1981). Dry rice agriculture in some } \\
\text { parts. }\end{array}$ \\
\hline 8 & $\begin{array}{l}\text { Only a negotiated oral history } \\
\text { exists in a structure of myths } \\
\text { and legends which cannot be } \\
\text { conclusively verified. }\end{array}$ & $\begin{array}{l}\text { Historical records written on Lontar } \\
\text { made from wood or copper and dating } \\
\text { from } 900 \mathrm{AD} \text {. Local oral histories that } \\
\text { cannot be conclusively verified and } \\
\text { are often of an explicitly mythological } \\
\text { character. }\end{array}$ \\
\hline 9 & $\begin{array}{l}\text { BaliAgaarchitectureand village } \\
\text { structure have configurations } \\
\text { that are very specific. Bali Aga } \\
\text { have their own lontar undagi / } \\
\text { asta kosala. Ancestral houses or } \\
\text { temples have complex spatial } \\
\text { structure. }\end{array}$ & $\begin{array}{l}\text { Geometrical principles based in Hindu } \\
\text { philosophy structure space in buildings } \\
\text { and villages. Use of cardinal compass } \\
\text { points, spatial templates (Nawa Sanga, } \\
\text { Chatus Patha etc. Linear elements are } \\
\text { frequently significant). }\end{array}$ \\
\hline 10 & $\begin{array}{l}\text { Varied acceptance by Bali } \\
\text { Aga of the term Bali Aga due } \\
\text { to its potential implications } \\
\text { of backwardness and sub- } \\
\text { servience. }\end{array}$ & $\begin{array}{l}\text { Unique terminology in common use but } \\
\text { with varying degrees of acceptance and } \\
\text { meaning depending on the context. }\end{array}$ \\
\hline 11 & $\begin{array}{l}\text { Possess 'democratic' insti- } \\
\text { tutions seniority over more } \\
\text { marginal relationship to the } \\
\text { state. }\end{array}$ & $\begin{array}{l}\text { Main institutions are hierarchic and } \\
\text { recently more integrated with state } \\
\text { ideologies via urban planning and } \\
\text { legislative mandates. e.g. the training of } \\
\text { Adat leaders via Badan Pelaksana Pembina } \\
\text { Lembaga Adat and ritual simplification via } \\
\text { Parisada Hindu Dharma Indonesia. }\end{array}$ \\
\hline 12 & $\begin{array}{l}\text { Lowland Balinese festivals are } \\
\text { not recognised or are held at } \\
\text { different times. Main festivals } \\
\text { follow the annual cycle of the } \\
\text { sasih calendar. }\end{array}$ & $\begin{array}{l}\text { Wukucalendarbasedannualcelebrations } \\
\text { such as Galungan, and Kuningan are } \\
\text { the most important celebrations and } \\
\text { symbolic markers in social life along } \\
\text { with Nyepi based in the Caka year. }\end{array}$ \\
\hline 13 & $\begin{array}{l}\text { Social structure less susceptible } \\
\text { to manipulation due to its non- } \\
\text { material organisation, and } \\
\text { non-uniform social practices. }\end{array}$ & $\begin{array}{l}\text { Social structure prone to domination due } \\
\text { to hierarchic social formation, the use of } \\
\text { subak (as in hydraulic societies), respect } \\
\text { for hierarchy (e.g. monarchy). Thus } \\
\text { pre-existing structures that facilitated } \\
\text { domination were potentially in place. }\end{array}$ \\
\hline
\end{tabular}




\begin{tabular}{|c|c|c|}
\hline 14 & $\begin{array}{l}\text { Social precedence according } \\
\text { to seniority status where in } \\
\text { theory material society has no } \\
\text { influence. }\end{array}$ & $\begin{array}{l}\text { Hierarchy established on the basis } \\
\text { of caste, class, claimed proximity to } \\
\text { monarchies, and material wealth. }\end{array}$ \\
\hline 15 & $\begin{array}{l}\text { Religious centres correspond } \\
\text { to locations of mytho-historical } \\
\text { ancestors. }\end{array}$ & $\begin{array}{l}\text { Religious centres are sited based on } \\
\text { mythic association, recognising design } \\
\text { principles such as Nawa Sanga etc. But } \\
\text { mythic ancestors and sacred landscape } \\
\text { are also important. }\end{array}$ \\
\hline 16 & Animal sacrifice is significant. & $\begin{array}{l}\text { Blood sacrifice remains significant but to } \\
\text { a lesser extent. }\end{array}$ \\
\hline 17 & $\begin{array}{l}\text { Balinese high language (alus) } \\
\text { is rarely used. }\end{array}$ & $\begin{array}{l}\text { Three levels of Balinese are traditionally } \\
\text { spoken. }\end{array}$ \\
\hline 18 & $\begin{array}{l}\text { Philosophical tenets based } \\
\text { primarily upon dualism } \\
\text { (dyadic forms). Balance created } \\
\text { by opposites. }\end{array}$ & $\begin{array}{l}\text { Lowland Balinese cosmology is often } \\
\text { triadic, embedded in the concept of TrI } \\
\text { Angga or Tri loka. Overemphasised in } \\
\text { recent decades at the expense of older } \\
\text { more dyadic substructures. }\end{array}$ \\
\hline 19 & $\begin{array}{l}\text { Aga villages tend towards a } \\
\text { dualistic structure and form. }\end{array}$ & $\begin{array}{l}\text { Lowland Balinese villages are codified } \\
\text { in the same manner as domestic } \\
\text { dwellings. }\end{array}$ \\
\hline 20 & $\begin{array}{l}\text { Bali Aga villages are ge- } \\
\text { rontocratic (ruled by old } \\
\text { people) but marital status is } \\
\text { also significant. }\end{array}$ & $\begin{array}{l}\text { Villages are recently governed on } \\
\text { the basis of democratic processes of } \\
\text { election. Traditionally they share greater } \\
\text { similarity with Bali Aga. Office holders } \\
\text { tend to be high caste (Satria). }\end{array}$ \\
\hline
\end{tabular}

The above table proposes a series of generalised distinctions between Aga Bali and Lowland Balinese cultures. Specific examples can be found that will contradict any item in the table. Due to the incredible complexity of social relations, all items are suspect, even the term Banua, which is the basic spatial unit of their culture cannot be uniformly applied. Rather than abandon any attempts at comparison, we would claim that there remains value in this process provided that limitations are stated. Recognising this fact, exemplary exceptions to general rules are included throughout the text. 


\section{Precedence and status}

Reuter notes that the term precedence stands for a basic set of logical principles through which status is negotiated and differentiated in many Austronesian-speaking societies (61). He maintains that status relations may be conflated to power relations since both require the accumulation of symbolic capital in the process of realising status. Significantly he also states that his model 'is no longer a model for living, but a model of another life' (57). But the concept of status not only applies to Bali Aga. This is clearly a universal concept with infinite variations and powerful historical associations and that include our globalised post-modern world. Hence precedence and caste are only two culturally distinctive way of establishing status. Many others exist. Status usually refers to one's social position in a hierarchy of social relations based largely in material wealth. We use the term hierarchy here as it is used in general in the social sciences to denote status and authority, bypassing Dumont's concept of hierarchy which was perhaps appropriate until the middle ages. There is no need to base one's analysis of symbolic hierarchies solely on religion as Reuter suggests (after Dumont). But what other factors are involved in its definition?

Status in modern society is frequently based on inheritance and cultural capital (monarchies and their coterie of sycophants as in Britain, Denmark etc., and to an extent in Bali), accumulated wealth through commerce, and now cultural capital in the form of education and other symbolic resources. Indeed what has been called the knowledge class now plays a significant role in cultural production and the wealth of cities (Florida 2003, 2005). Previously, while social class (or indeed caste) by itself was historically sufficient to connote status, to this we can now add symbolic capital, and the anxieties that go with it - what has been termed status anxiety - the feeling that somehow your symbolic capital is inadequate to your desired position in society (De Botton 2005). It is insufficient merely to be wealthy or well 'bred' - education, learning, possessions and the choices one makes - one's taste -, all play a role. Taste then becomes a currency, which in turn generates a cultural economy served by capital.

In this environment, Bourdieu (whom Reuter apparently respects) - extends the Marxian use of the term capital to the individual rather than the economy, and suggests that our lives 
are composed of four forms of capital, - economic capital (material wealth), cultural capital (education), social capital (lineage and connections) and symbolic capital (status); see also Marx (1981). In addition these forms of capital can be exchanged in dealing with other people and are woven together in complex ways that define our lives as social beings. The degree of possession of these forms of capital therefore determine one's place in the overall social hierarchy, but the agency through which they are deployed in living our lives is what Bourdieu calls habitus 'the learned dispositions such as bodily comportment, ways of speaking, or ways of thinking and acting which are adopted by people in relation to the social conditions in which they exist and move through' (Giddens 2009: 846). Reuter only considers one of these dimensions, that of symbolic capital, and the others do not surface as having any real significance in this particular case. So it remains to be seen whether or not these ideas are valid for Bali Aga people living in a postmodern age and whether consideration of only one of Bourdieu's dimensions of capital is appropriate for Bali Aga culture.

But according to Reuter, the accumulation of symbolic capital is all consuming and material wealth appears to play little part in this process. The status of individuals is determined by their proximity to the first ancestors and not to material possessions or to any other social hierarchy. Reuter maintains that the consequence is a non-hierarchic society since descriptors of hierarchy usually imply caste, class and/or material wealth as in Lowland Balinese culture - a terminology that Bali Aga do not use (see table 1 for comparisons). Again, this is due to his assumption that they do not have a hierarchical society in Dumont's sense, one based upon religion and precedence as the qualifiers, and one which in this case is self-fulfilling. We would argue that their status system is clearly hierarchic - only the terms of reference are different. Status is conveyed through origin narratives (mythologies or stories) which are rated by order of precedence, the earliest possessing the greatest symbolic capital. Surely this constitutes a hierarchic structure, albeit an exception to the stated criteria?

The confusion here would appear to be the conflation of hierarchy with power, and this is a contingentidea. Status (hierarchy) for Bali Aga has many prevailing dimensions which reflect e.g. the division of ceremonial labour and ritual sacrifice, proximity to 
origins, seating order and position at ceremonial events and in the distribution of holy water and leftover ceremonial food offerings. He also states that claims to precedence can be contested at two levels, first, whether the event dictating precedence ever happened, and second, whether such events are relevant for determining social status at all. He suggests that Bali Aga theories of society and sociological theories of society may have limited benefits in practice, maintaining that these remain discourses not practices. Both within and between societies there will be significant variation. While this may seem to be a universal law, George Lukacs had a point when he maintained that ideologies (discourses) are lived systems of value and to that degree people do not need to theorise what they do in order to do it. In other words it is possible to maintain one's conditions of existence without any artificial separation between representational categories.

Overall the case for a status society under conditions where their material economy is not discussed, along with the idea that they represent a non-hierarchic social culture is difficult to maintain, particularly since e.g. patriarchy and gendered roles are universally impacted. Significantly however, this does not imply that Reuter is incorrect. It simply means that his case is not proven. Despite this, Reuter is categorical about the issue, where he disagrees with Pierre Bourdieu regarding the conversion of symbolic power into material power i.e. 'status is a relatively inalienable resource.... with no reduction of one to the other....status is an end in itself' (40), Milner (1994). To elaborate on this position we must now seek a more involved explanation of representation and its implications for status.

\section{Representation}

In regard to the representation of Bali Aga, Reuter comments:

While power differences may not be a major factor in shaping the mutual representations they have constructed of one another, they have also participated and competed - with a distinct disadvantage - on the larger stage of a Balinese politics of identity.....A further set of questions is thus raised...... How have the Bali Aga been represented by more powerful others and how have they represented themselves to the outside world? Or put in more general terms, how does representation function under a condition of a material disparity? (5) (our italics). 
Here Reuter is quite clear that intentionally or otherwise, Bali Aga have been misrepresented; arguably victimised by naming. The very term Bali Aga (mountain people) can be viewed as a marginalising concept used by lowland Balinese, contemporary scholars, the state and other elite groups all of which adds up to Bali Aga having the doubtful status in the minds of anthropologists of 'cultural oddities and isolates' (Hobart et al 1996), (302). Bali Aga themselves are not indifferent to these distinctions, and the term 'Bali Aga' is frequently unacceptable, with 'the inhabitants of Trunyan on Lake Batur considering it 'degrading and humiliating' (ibid :27). For others, e.g. Tenganan, the term is a source of pride, but we may speculate that this is the exception rather than the rule, given the cloistered nature of Tenganan people. Reuter argues that this has not been a rapid event. The process of alienation has taken place at least since the Majapahit invasions, and later, the flight from Islam by Javanese Hindus. This situation was exacerbated through the consolidation of the Lowland Balinese kingdoms, colonisation by the Dutch, the consolidation of a modern state, and globalisation, each in its own way had a specific impact. The establishment of a new monarchic political order and class structure with the Majapahit invasion resulted in commoners being referred to as anak jaba (outsiders) from which Bali Aga managed to exclude themselves with yet another level of alienation as mountain people.

The geography has also on occasion, been used in a discriminating manner, since lowland, south, and coastal have been used to denote 'inferior' to highland, north, and mountain, in the same manner that the term Global North frequently denotes advanced civilisation, material abundance, democratic institutions, whereas as the Global South can denote poverty, decayed or deranged social structures, despotic control, absence of law and order, and the oppression of subaltern peoples. Reuter notes that if the north eastern coast was denoted as the significant littoral region, then there would be no empirical ground for any cultural divide (20). In reality its significance was a historical event due to trade with Asia. Today the North coast has hardly any important function in the Balinese economy, given that the major ports are all on the south coast. The Architecture and spectacles of the South are frequently 
associated with that of 'higher culture'. Bali Aga ceremonies fade in comparison to the spectacles provided by Lowland Balinese rituals. But arguably from a social perspective those of the Bali Aga are more complex because priests are not in charge of orchestrating ceremonies. So the performance dimension of lowland Balinese spectacles is replaced in the Bali Aga by a more democratic, 'grass roots' ownership of their own rituals. Here the distinction between 'high' and 'low' culture has no merit, remaining a discriminating concept where Bali Aga then become desa tertinggal or backward people in terms of cultural production (Adorno 1991).

What this suggests is that any generalisations of Bali Aga culture must be highly qualified with the distinction that you will always find some community that challenges any general principle. Naturally the state plays its part, since the agenda of every state is to ensure sufficient primacy over sub cultures to guarantee domination, an adopted method being the homogenising of cultural values. In Indonesia this was enshrined in the Badan Pelaksana Pembina Lembaga Adat for the island of Bali where the intention is to make the differences between individual village cultures less acute (286-287). For Reuter, all of this adds up to the fact that 'It seems Bali Aga culture has been earmarked for systematic destruction' (287), Although many would disagree with this viewpoint today, they were certainly under pressure during the New Order's adat policy in the 1990s when fieldwork was undertaken for Custodians. Nonetheless, while Bali Aga may exist within a mythical culture they are not a mythical people, they live in time and space like everyone else, since 'social processes do not happen on the head of a pin. Objects have spatial extension and two or more of them cannot occupy the same space simultaneously' (Sayer 1984:134). So we now turn to the dimensions of place and space in order to ground Bali Aga in the material reality of their own making.

\section{Banua, typology and place}

Reuter's interest in space derives from its association with status and ritual, 'The local kinship system is based on a logic of genealogical ancestry with a broader notion of spatiotemporal positioning pertaining to the houses of the living and the temples of the ancestors' (236). This has direct implication for his focus on 
the geographic foundation of the banua. The singularity of Bali Aga life and cultural identity cannot take place without this focus. As a people they are not merely a reflection of the rituals they perform in several hundred separate villages scattered across the landscape, and studied independently of one another. Their coherence as a people depends on how they inhabit space, how proximal relations take place, where sacred and profane functions are both located, and how buildings and places are sited or acquire their identity. Regional alliance networks are the foundation for social organisation known as banua or what Reuter refers to as ritual domains.

In English, a domain refers to the word territory, but usually one under some form of social control, rather than e.g. a desert. So in essence the term banua is a spatial form that is essential to understanding the structuring and importance of settlement patterns and locations. Banua encompass a regional network of villages that exist in a hierarchy of symbolic interactions based upon proximity to their mythical origins, thus:

The Bali Aga conceive of contemporary society as a differentiated whole arising from a common source in the past, and expanding in a historical sequence of migrations and village foundations...villages within a domain therefore represent way-stations on the path of the ancestors, and the ritual status of a particular village is determined by precedence or relative proximity to the sacred origin of this mythical journey.

Hence 'any immediate concern for regulating access to land has been abandoned' (32). So in fact it is the people that are owned rather than the land. At least in theory, the elementary rule is that the land cannot be owned, and the extent to which the various forms of 'ownership' that exist today impact politically on Aga life remains unaddressed. Spatial units exist in the absence of any concept of ownership as in the market system, although this has changed considerably in the last twenty years raising the issue of an incipient landlord class and nascent class structure. Land is in fact communally owned in many Bali Aga villages, a process called tanah ayahan, thus allowing land to be nominally owned by the ancestral gods who then ensure the land's fertility. From page 38-54 Reuter enunciates four typologies/types of banua, and it is important to recognise that these constitute spatial typologies, not 
only typologies of social relations. These are:

1 Typology 1. A small cluster of villages where one of these is regarded as the first and original 'village of the domain.' Bayung Gede and Penglipuran are examples of this banua, Penglipuran being a downstream pondokan founded from ancestors of Bayung Gede.

2 Typology 2. Where the common source of the village is said to have been destroyed or abandoned at some historical moment i.e. it has a socially vacant origin site e.g. Pura Tebanan. The internal precedence ranking between villages is therefore unclear.

3 Typology 3. Where the banua is based upon a history of immigration and therefore of multiple sacred origins. The immigrants in this type of banua are recognised as founders of subsidiary villages within the territory of a large original village. Desa Selulung is an example of such a core village.

4 Typology 4. The larger banua centred on the summit temples such as Pura Pucak Penulisan, Pura Pujak Tahjun, and Pura Pucak Mangu.

Pura Batur is one exception to these cases since peturunan payments are not required, and therefore a different social contract exists (this is another type of exception qualifying Table 1 above). Reuter notes that Batur's temple elders nowadays prefer a proMajapahit discourse claiming their temple to be one of Bali's six major sanctuaries (Sad Kayangan). He also notes that Pura Batur has a support structure of 45 villages as well as many other subak. It is also possible that these four banua typologies might have resulted in four different spatial typologies i.e. various similar configurations of village structure might also exist, but it would need to be researched as to whether or not this was the case.

Banua is the largest organisational, ritual and spatial unit, a word that retains its Austronesian roots. At the same time Reuter warns against a narrow definition of banua, since it has multiple meanings dependent on speech context - desa banua (origin village); gebog banua (set of villages); pura banua (central temple); keraman banua (congregation of heads of households) etc. While the term banua is a complex of material, human and spiritual dimensions, 
the term gebog refers to the social association among a set of villages (38). So it seems possible to conceive of a banua as being composed of a series of gebog, which collectively will have a greater ritual obligation to the pura banua than they do to each other. In turn each gebog is composed of several desa (villages) of varying sizes and compositions. The Banua of Pura Puncak Penulisan had a population of 33,000 persons (approx.7,400 households) in 2002. It had four gebog (Sukawana, Selelung, Bantang and Kintamani) which collectively possessed 30 desa. Sites of origin are located at the centre of the Banua which need not necessarily be the geographic centre. Similarly, the physical proximity of a village to the Pura Banua has no significance in terms of its status, it is the mytho-historical proximity that counts.

Similarly, and in contrast to Lowland Balinese culture which adopted spatial 'codes' for everything from the layout of towns and villages, to the zoning of house compounds and the design of individual buildings and building complexes, Bali Aga have their own architectural concepts that regulate all domestic spaces, along with a unique version of Asta Kosala Kosali. The possible exception to this rule is in the internal layout of domestic dwellings, which includes positioning of the shrine, sleeping area etc. Their houses contain most domestic activities, zoned within different sections of a dwelling, unlike those of the lowland where vernacular housing is zoned as a series of dwellings with separate functions within a compound according to the Nawa Sanga (Suartika 2013c). While settlements such as Penglipuran and Tenganan have highly articulated forms, these are very much the exception to the rule (see Reuter 1998). 


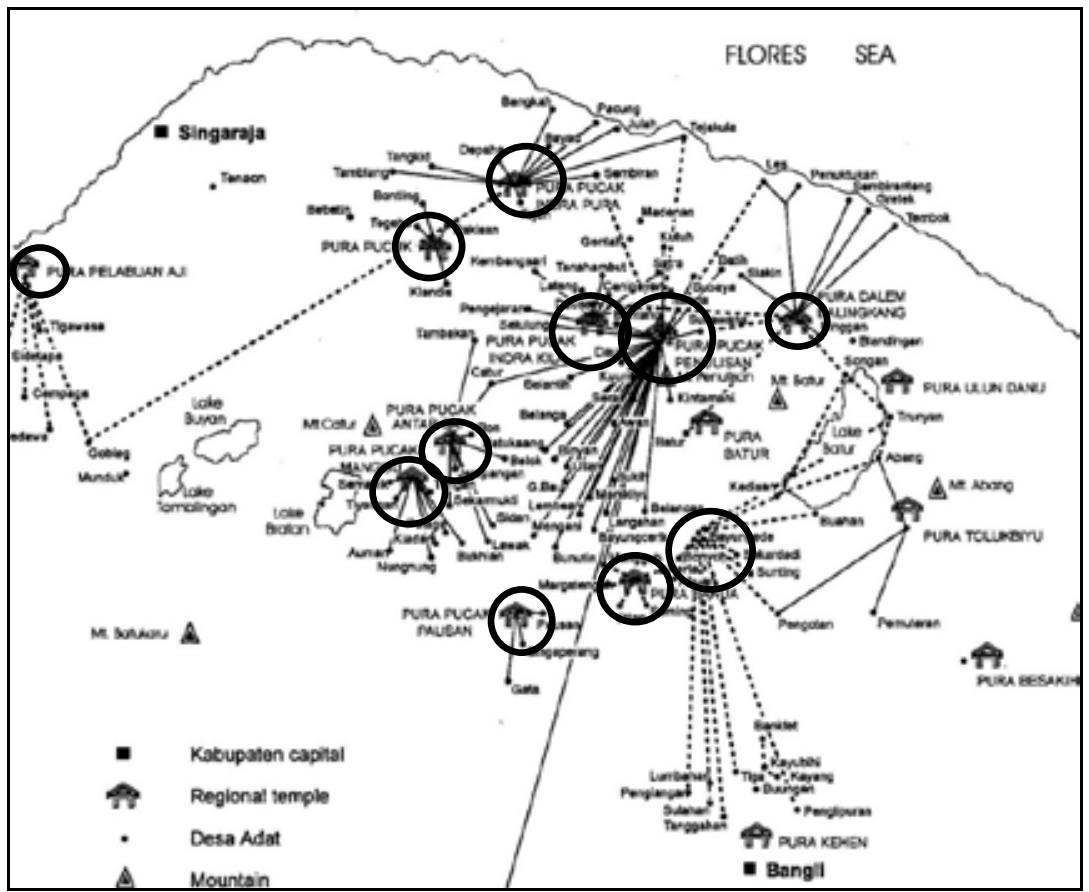

Figure 3. Ritual networks in the Highlands of Bali. Adapted from Thomas Reuter 2002:51.

\section{The Mental and the Material}

As we have indicated above, it is difficult if not impossible to represent any culture purely on the basis of status, Bali Aga or otherwise. In the Custodians of the Sacred Mountains, the material life of Bali Aga has simply vanished from consideration, on the basis that their social hierarchy is not materially based. But this leaves many questions unexplained, since a symbolic economy as defined cannot exist at all without a material economy as its foundation. Ceremonies, rituals, and other cultural events alone do not sustain life and so the material i.e. economic relations, remain fundamental. The term 'economy' is defined in the Oxford Dictionary as 'the wealth and resources of a country or region, especially in terms of the production and consumption of goods and services' Hence the use of the term symbolic economy is seriously misleading since no economic principles apply. There is no consideration of the terminology which treats status as a form of capital. This theoretical framework existed at the time the book was written, emanating from 
Bourdieu's ideas on status and Baudrillard's elaboration of the four forms of capital (use value/utility/instrument; exchange value/the market/commodity; symbolic exchange/gift; and sign value/status). Overall, this would have resulted overall in a more believable set of outcomes. Later in clarifying this position somewhat, Reuter recognises that a political economy exists (pp. 245-9). Given that this is not explained, it is difficult to support his thesis since all economies have regional dimensions:

This is not to deny that Bali Aga society has an economic and political economy, as it certainly does, or that economic and political economies lack an important symbolic dimension. I am arguing only that politics and economics do not operate very strongly in this society at a regional level...p 245.

While this may be true, this is a speculation not a fact, opening up criticism of the Custodians which leads to an essentialising model of society 'which is predominantly run by institutions and in which individual actors and their perspectives and concerns remain invisible' (Schulte Nordholt 2003:136). More importantly, traditional culture exists in the realm of consumption not production (at least prior to the cultural economies of post modernity, see Scott 2000). Symbolism qua culture constitutes non-productive labour that consumes resources but does not contribute to material life. The onus on status therefore immediately precipitates a state of entropy which is clearly illogical. No culture can last without acting productively on its own environment, and this must happen in some form. How then do people survive, and how are socio-spatial relations constituted by the production of material wealth impact on Bali Aga, whether or not it contributes to a status hierarchy? While it is clear that the lowlands contain the centres of production and economy, as well as the dominant revenues from global tourism and there is a massive trickle-down effect, this is not the case in the highlands. How therefore are elaborate temples, ceremonies, rituals and performances afforded by tens, possibly hundreds of thousands of Bali Aga? While the costs are large and divided among the population, with all labour provided free, an explanation as to the source of the capital is absent, and this remains a critical omission in the Custodians. Nonetheless Reuter still suggests that the symbolic economy of status is more important than the material 
economy of the production of the means of subsistence i.e. staying alive:

Human beings are not a species that are content to live in society, but a species which produces society in order to live - in other words [one which] invents new modes of organisation and thought (Godelier 2012: 16)

Consequently, in regard to more developed economies, a classic materialist approach would adopt the following basic principles, where culture is relegated to the superstructure. With the means of production and relations of production combined in the base. Reuter rejects this idea when he refers to the accumulation of cultural capital as their means of production, which usually encompass raw materials, capital goods, labour power and technology (Table 2), which then become 'cooperative processes of representation' (10).

\section{Ideology (Superstructure)}

(Non-economic institutions e.g. culture, religion, law)

(Economic institutions and relations, labour, workshops etc.)

The Base: Infrastructure (Economy)

What may be inferred from this as a broad generalisation is that this table should be turned upside down, where the base symbolic economy somehow supports or replaces the material. On this basis we could then argue that the diagram becomes irrelevant. The agency through which this process takes place is ritual, which Reuter suggests diminishes the relationship between status and labour, thus reducing the value of material life as a determinant of status hierarchies. This symbolic determinism thesis allows any analysis of the labour process to be set to one side, and to adopt a status economy approach rather than a political economy approach, where symbolic resources replace material resources as determinants of status. But as Pierre Bourdieu remarks,

Every type of capital (economic, social, and cultural) tends to different degrees to function as symbolic capital (so that it might be better to speak of the symbolic effects of capital)......symbolic capital rescues agents from insignificance, the absence of importance and meaning. (Bourdieu 2000:242). 
So there are clues throughout the text that something is missing. Rather than spending so much time 'in what is basically a crusade against postmodern anthropology' (Schulte Nordholt 134), had more space been given to position his research as a critique of historical materialism, a more convincing study would have emerged. This would have demanded a lesser concentration on ethnography, and an additional emphasis on epistemology - the method of connecting material events to thoughts and ideas. There are also questions remaining regarding the state, the availability and forms of capital, class structures outside of the symbolic economy etc. Whereas Reuter rejects a political economy approach, at the same time he does not say what he understands this to be despite its immense history, commencing with Adam Smith in 1775 , and continuing today as a major branch of social science. In the given space, it is impossible to outline this particular field, and reference should be made to authors such as Stillwell (2002), (Clark and Dear 1984), and Harvey $(1985,2007)$. None of these scholars are anthropologists, whose field is best described as spatial political economy. A basic principle of political economy is that all societies consume less than they produce. Hence surplus product is created. In capitalist societies this surplus is collectively produced but privately appropriated, creating a class structure of wage earners on the one hand and owners of the means of production on the other. The agency that mediates in the implicit conflicts of such social systems is called 'the state', where a prime obligation is to supply land for private development via planning practice (Suartika 2007, 2010, Giddens 1984).

In the case of Bali Aga these principles are difficult to apply since it is a pre-capitalist social form living within capitalism. Historically they constituted a society which has evolved within the development of capitalist social relations but arguably is not of them. Reuter is arguably the first to define Bali Aga with its own homogeneity and as something other than a distortion of feudalism. At the same time, Bali Aga society has resisted in principle many of its assumptions e.g. private ownership of land, appropriation of the surplus, the resulting class system and a status economy that is constructed on completely differing principles, the main one being the defining property of control over the means of production by a 
dominant class of landowners. None of this however denies that a material economy exists, so other problems arise for the Custodians of the Sacred Mountains. Overall the dynamic interaction of land, labour and capital, foundations of any economy, are only hinted at, and the carrying capacity of a low density mountain economy is not investigated. Despite this Reuter understands the significance of the mountains to the domestic economy as a whole, and for the historical existence of trade routes in both directions through mountainous areas inhabited by Bali Aga. This situation was enhanced by the northern shore being the first point of arrival for traders, who had access to a variety of harbours which permitted the offloading of goods. Clearly both the significance of geography and land ownership/ control have been, and remain important. Reuter also indicates the political influence of land as a resource, where the integrity of a domain can be challenged by control over land. Here disputes have in some situations threatened the prevailing social order, and 'is accentuated by the economic and political autonomy of contemporary branch villages' that have managed to capture use values over this limited resource despite its collective ownership ( $\mathrm{pp}$ 214-5). He also notes the influence of the modern state, and that today (2002) Bali Aga are enjoying increased autonomy. Farmers are also becoming wealthy through the use of new technologies of production, (313). Even at that time the impact of material production was increasing in its significance. Since subsistence farming has now all but disappeared, a cash crop economy prevails across Bali Aga Society and it remains to be seen whether the status economy or the political economy of land development inevitably wins out.

Paradoxically the same factors are also undermining their culture in terms of their traditional housing, as indeed it is in Lowland Balinese culture as well, but for different reasons. The private ownership of dwellings in Lowland Balinese culture also carries a custodial significance within the context where the family shrine represents the symbolic presence of the ancestors, and hence will virtually never be sold. This represents a barrier to capital accumulation since it removes significant amounts of land from the market system, hence threatening development (Suartika 2007). Bali Aga have been targeted somewhat differently, as a backward and under-educated social community (desa tertinggal) by the 
Indonesian government, and therefore are eligible for government grants (low interest loans) to 'advance' themselves by destroying their traditions and building concrete structures instead. Then they may have to sell land to meet repayments on the loan, since privately owned land, of which there is a varying amount in different Aga villages, can be sold.

Hence the major beneficiaries of the funding system are village elites who may redirect the loans to more profitable forms of investment (pp. 283-4). More importantly, this presumably would have an effect on the communal relationships built up around mutual help and support. So Bali Aga have inadvertently been sucked into an incipient dependency on the state, one which undermines the very principles upon which their society is built. This effectively begins a process of increased reliance on material rather than symbolic resources, and the generation of an incipient class system based on systematic economic exploitation by their own people. In addition, private capital is also involved since e.g. one third of Pura Penulisan's income derives from private sources (103). So even in Custodians of the Sacred Mountain there are sufficient clues that the material economy exists to warrant another text that seeks to integrate the mental and material aspects of Bali Aga.

\section{Conclusion}

Reuter's text represents a significant challenge to traditional studies of Bali Aga, given his regional approach and the pursuit of a status economy. But since his status economy is the determinant of social relations, not capital, then the idea of an economic infrastructure does not enter the picture and this is problematic. We are left with culture (or superstructures) without a material foundation to permit life to continue. Alternatively one could also argue that Reuter does not need to explain the material foundation of Bali Aga economy, since his focus is on status, not material wealth. While Reuter does not say that political economy is unimportant, he does maintain that it is a level playing field in this case, which is why the symbolic process can be observed undisturbed. Nonetheless, one half of the playing field remains invisible and this unnecessarily exposes the text to the criticisms of reductionism and essentialism.

Despite the imponderable nature of the idea, culture in this context remains superstructural i.e. it consumes resources (wealth), 
but produces none, unlike the cultural economy of contemporary social life (Scott 2000). The crucial question here is 'why it is both necessary and important to detach the mental from the material in this manner?' It would seem that arguments in favour of a status economy would in fact be strengthened by a parallel account of the basis for life, without weakening the idea that histories, mythologies and traditions are important. This omission may be partly explained in Reuter's approach to culture as a system. The concept system can only function effectively if the properties demanded by the existence of the system are highly constrained, as in the case of the status economy (Sayer 1976; 1984). In adopting a status economy as the basic paradigm, an inherent property of all models is revealed. For the model to work, contingency dominates, but many necessary features affecting the model must be excluded since it is impossible to model everything (Sayer 1976). In other words, a model by its very existence demands that the odds are stacked in its favour from the very beginning. Hence a systems approach may be viewed as the requisite design of partial truths in the interest of expediency. In Reuter's case this means that by deleting the political economy of the region from the start, it becomes significantly easier to demonstrate the singularity of a status economy. So the daily lives of over 100,000 people are omitted in favour of an explanation that does not accommodate the inhabitant's basic conditions of existence. Does this not, in Habermas' terminology, result in distorted communication where Bali Aga appear to float free of the physical world of resource creation, accumulation and distribution? Whether this is reasonable criticism or not is up to the reader to judge.

But as we have stated above, the production of symbolic capital does not replace the production of other forms of capital, or indeed how these forms morph into each other. So somehow the concept that one form of capital dominates in isolation to another three seems improbable, or as Bourdieu comments- 'All that needs to be abandoned is the empty claim that the struggle for symbolic capital alone constitutes human beings in the social field.'(Bourdieu in Schusterman 1999:91). The idea of limiting a problem in order to study it applies to all fields of knowledge. But this process also carries penalties. However Bali Aga are studied, they now live within a global capitalist world. They buy cars, refrigerators, 
own property, watch television, drink coca cola, meet tourists, use cellphones, access the internet and chatrooms, send their children to school, and are studied by anthropologists from distant places, all of which exist outside the narrow concept of a ritually defined status society. So in conclusion, Reuter's overarching concentration on the status economy to the extent that the political economy is omitted is counter-productive in explaining the reality of a unique and fascinating culture.

\section{Bibliography}

Adorno T. 1991. The Culture Industry. London: Routledge.

Agger, B. 1992. Cultural Studies as Critical Theory. London: Palmer Press.

Althusser, L. 1965. For Marx. London: Allen Lane.

Blaikie, N. 1993. Approaches to Social Enquiry. Polity Press: Cambridge.

Bourdieu, P. 1977. Outline of a Theory of Practice. New York: Cambridge University Press.

Bourdieu, P. 1986. The Forms of Capital. In J. G. Richardson ed., Handbook of Theory and Research of the Sociology of Education. New York. Greenwood Press.

London: Tavistock. Chapter 1: 27-42.

Clark, G. L. and Dear, M. 1981. State Apparatus - Structures and Language of legitimacy. London: Allen and Unwin.

Cohen, G. A. 1978. Karl Marx' Theory of History - A Defence. Oxford: Oxford University Press.

Covarrubias, M. 1972. (original 1937). Island of Bali. Kuala Lumpur: Oxford University Press.

Cribb, R. (ed.) 1990. The Indonesian Killings of 1965-66. Clayton: Monash University.

Cuthbert A.R. 2011. Understanding Cities. London: Routledge.

Cuthbert, A. R. 2012. Paradise lost, sanity gained - towards a critical Balinese urbanism. Jurnal Kajian Bali. 2 (1) 1-40.

Cuthbert. A. R. and Suartika, G.A. M. 2014. The Theatre of the Universe - Culture and Urban Design. The Journal of Urban Design. 19 (3).

De Botton, A. 2005. Status Anxiety. New York: Vintage. 
Hlm. 259-298 Revisiting Reuter: Symbolic and material economies in Bali aga society

De Certeau. M. 1988. The Writing of History. New York: Columbia University Press.

Duara, P. 1995a. Rescuing History from the Nation: Questioning Narratives of Modern China. Chicago: University of Chicago Press.

Duara, P. 1998. Why is History Antitheoretical? Modern China, Vol. 24, No. 2, History Research. Chicago: University of Chicago Press.

Paradigmatic Issues in Chinese Studies, Part V (Apr., 1998), pp. 105120. Sage Publications, Inc.

Feyerabend, P. 1975. Against Method. London: Verso.

Feyerabend, P. 1987. Farewell to Reason. London: Verso.

Florida R. 2005. The Flight of the Creative Class. New York: Vantage Books.

Florida, R. 2003. The Rise of the Creative Class. London: Pluto Press.

Fukuyama, F. 1992. The End of History and the Last Man. New York: The Free Press.

Fulbrook, M. 2002. Historical Theory. London: Routledge.

Geertz, C. 1973. The Interpretation of Cultures. New York: Basic Books.

Geertz, C. 1980. Negara. The Theatre State in $19^{\text {th }}$ Century Bali. Princeton: Princeton U.P.

Giddens, A. 1984. The Constitution of Society -Outline of the Theory of Structuration. Cambridge: Polity Press.

Giddens, A. 2006. Sociology. Cambridge: Polity Press.

Godelier, M. 1985. The Mental and the Material - Thought, Economy and Society. London: Verso.

H. Schulte- Nordholt. The Spell of Power - The History of Balinese Politics 1650-1940. Leiden: KITLV Press.

Habermas, J. 1970: Towards a theory of communicative competence. Inquiry: An Interdisciplinary Journal of Philosophy, 13(1) 360 - 375.

Habermas, J. 1979. Communication and the Evolution of Society. Toronto: Beacon Press

Harvey, D. 1973. Social Justice and the City. London: Arnold.

Harvey, D. 1985. The Urbanisation of Capital. Oxford: Blackwell.

Harvey, D. 2007. Spaces of Global Capitalism: Towards a Theory of Uneven Geographical Development. London: Verso.

Hauser-Schäublin, B. 2008. Ritual, Pilgrimage and the Reconfiguration 
of the State. Sacred Journeys in the Political Landscape of Bali (Indonesia). In: Gengnagel, J., Horstmann, M., Schwedler, G. (eds.): Prozessionen, Wallfahrten, Aufmärsche: Bewegung zwischen Religion und Politik in Europa und Asien seit dem Mittelalter, pp. 269-289. Vienna: Böhlau 2008

Hobart, H. Ramseyer, U. and Leeman, A. 1996. The Peoples of Bali. Oxford: Blackwell.

Hobart, M. 2000. After Culture: Anthropology as Radical Metaphysical Critique. Yogyakarta: Duta Wacana University Press.

Ingold, T. 2013. Making: Anthropology, Archaeology, Art and Architecture. Routledge, London.

Ingold, T. 2015. The Life of Lines. Routledge, Abingdon.

Karafet, Tatiana M.; Lansing, J S.; Redd, Alan J.; and Reznikova, Svetlana (2005) "Balinese Y-Chromosome Perspective on the Peopling of Indonesia: Genetic Contributions from Pre-Neolithic HunterGatherers, Austronesian Farmers, and Indian Traders," Human Biology: Vol. 77: Iss. 1, Article 8.

Lansing, S. 1983. Three Worlds of Bali. New York: Praegar.

Levi Strauss, C. 1969. The Raw and the Cooked. Mythologiques Vol 1. Chicago: University of Chicago Press.

Levi Strauss, C. 1978. Myth and Meaning-Cracking the Code of Culture. Toronto: University of Toronto Press.

Lewis, J. and B. Lewis. 2009. Bali's Silent Crisis - Desire, Tragedy and Transition. Plymouth: Lexington Books.

Marx. K. 1981 (orig 1845). The German Ideology. New York: International Publishers.

Mehr, N. 2009. Constructive Bloodbath in Indonesia: The United States, Great Britain and the Mass Killings of 1965-1966. London: Spokesman books.

Mikula, M. 2008. Key Concepts in Cultural Studies. New York: Palgrave.

Milner, M. 1994. Status and Sacredness: A General Theory of Status Relations and analysis of Indian Culture. Oxford: Oxford University Press.

Noble, T. 2000. Social Theory and Social Change. Basingstoke. Palgrave.

Pedersen, L. 2003: Book Review. The Journal of Social Issues in South East Asia. 34 (1) 170-171. Institute of South East Asian Studies.

Rappoport, A. 1969. House, Form and Culture. Englewood Cliffs New 
Hlm. 259-298 Revisiting Reuter: Symbolic and material economies in Bali aga society

Jersey: Prentice- Hall.

Ramseyer, U. 2009. The Theatre of the Universe. Ritual and Art in Tenganan Pegeringsingan. Basel: Museum der Kulturen .

Reid, A. 1983: Slavery Bondage and Dependency in Southeast Asia. University of Queensland Press. London.

Reuter, T. A. 2002. Custodians of the Sacred Mountain-Culture and Society in the Highlands of Bali. Honolulu: University of Honolulu Press.

Reuter, T. A. 2002. The House of our Ancestors. Leiden: KITLV.

Reuter, T. 1998. Houses and compounds in the mountains of Bali. Pp 38-39. In J. Davison (ed) Indonesian Heritage : Architecture. Singapore. Editions Didier Millet.

Robinson, G. 1995. The Dark Side of Paradise - Political Violence in Bali. Ithaca: Cornell University Press.

Sayer, A. 1976. A critique of urban modelling. Progress in Planning, 6 (3), 187-254.

Sayer, A. 1984. Method in Social Science. London: Hutchison.

Schulte - Nordholt, H. 1996. The Spell of Power. Leiden: KTLV.

Schulte - Nordholt, H. 2003. Review. The Journal of Social Issues in South East Asia. 34 (2) 133-135. Institute of South East Asian Studies.

Scott, A. J. 2000. The Cultural Economy of Cities. London: Sage.

Stillwell, F. 2002. Political Economy - The Contest of Economic Ideas. Melbourne: Oxford.

Suartika, G. A. M. 2007. Territoriality and the market system - Adat Land vs. State regulations on land matters in Bali. Habitat International. 31 (2, pp 167-176.

Suartika, G. A. M. 2010. Morphing Bali- The State, Planning and Culture. Saarbrucken: Lambert

Suartika, G.A.M. 2013c. Vernacular Transformations: Architecture, Place and Tradition. Denpasar, Bali: Pustaka Larasan.

Sulistiawati, A. 2013. Principles and Concepts of Balinese Traditional Architecture and Cultural Values. Chapter 10 pp 241-275. In Suartika, G. A. M. (2014) Vernacular Architecture. Denpasar: Pustaka Larasan.

Vickers, A. 1989. A Paradise Created: Victoria: Penguin Books.

Wälty, Samuel. 1997: Kintamani: Dorf, Land und Rituale. Entwicklung und institioneller Wandelin einer Bergregion auf Bali. Munstet: Lit Veriag. 
Warren, C. 1993. Adat and Dinas: Balinese communities in the Indonesian state. Kuala Lumpur, Oxford.

Wittfogel, K. A. 1981 (orig 1957). Oriental Despotism, A Comparative Study of Total Power.New Haven: Yale University Press.

\section{Websites contacted}

Figure 1.http://www.baliguide.com/bali-info/bali_map.html. Accessed 3/08/2016.

Karafet (bibliography) http://digitalcommons.wayne.edu/humbiol/ vol77/iss1/8 accessed 28/02/2016.

We would like to thank our two reviewers for their incisive and impartial critique of this manuscript. We hope that our comprehensive amendments have done justice to their contribution. In addition it should be mentioned that we have been discussing an important treatise published fifteen years ago, with research extending to five years prior. To this extent readers are advised to refer to Thomas Reuter's current publications, and should recognise that his own research has developed significantly from the above agenda. 